\title{
A Research on Poor Household of Coastal Community in South Sulawesi
}

\author{
Muhammad Idrus Taba ${ }^{1}$, Muhammad Sobarsyah ${ }^{2}$, Muhammad Ismail ${ }^{3}$, Fahrina Mustafa ${ }^{4}$ \\ \{idrus_taba@yahoo.com,msobarsyah@gmail.com,melph_ayie@yahoo.com,fahrinam@yahoo.com\} \\ Faculty of Economics and Business, Universitas Hasanuddin, Makassar, Indonesia ${ }^{1,2,3,4}$
}

\begin{abstract}
This research aimed to describe the characteristics of poor households including; age, education and main occupation and its relationship to the poor households' income level of coastal communities in South Sulawesi. Descriptive analysis was used in order to find out a general description of poor households' characteristics and Chi-Square Analysis to determine the relationship between social characteristics and poor household income. The results showed that the majority of respondents were in productive age (75 percent), had elementary school level of education (42 percent), and mostly work as fishermen (57.88 percent). Characteristics of age, education and main occupation have a significant relationship to family income. The relationship between socioeconomic characteristics with the level of family income was concluded that in the poor coastal community, productive age, education and occupation, were very important to get a better family income in order to maintain future socioeconomic welfare.
\end{abstract}

Keywords:

Characteristics of poor households and income of poor households

Article Received: 18 October 2020, Revised: 3 November 2020, Accepted: 24 December 2020

\section{Introduction}

Commitment to cope with the poverty problem is reflected constitutionally in the Constitution of 1945 . However, until 21st century, the level of poverty in Indonesia remains high. In the decade of 1976-1996, the percentage of poor community in Indonesia had experienced a decline from $40.1 \%$ to $11.3 \%$. But in the following period, during 1996-1998 this number became $24.29 \%$ or 49.5 million people. Even in 2014, the poor community did not experience a significant decline. The Central Statistics Agency (BPS) released data on the urban poor population in the number of 10.51 million in March 2014. Meanwhile, in rural areas, it was decreased by 17.77 million in March 2014. Even the International Labor Organization (ILO) estimates the number of poor people in Indonesia reaching 129.6 million or around $66.3 \%$.

During this time, various efforts have been made to overcome the poverty problem in Indonesia. A number of efforts have been made to overcome the poverty problem, including (i) Provision of Small and Medium Enterprises Loans, (ii) Presidential Instruction concerning the
Disadvantaged Villages (IDT); (iii) Prosperous Family Development Program through Prosperous Family Savings (Takesra)/Prosperous Family Business Credit (Kukesra); (iv) Farmer and Fishermen Income Improvement Projects (P4K); (v) Independent Young Family Business Group Social Welfare Program (Prokesos KUBE KMM); (vi) Social Safety Net Program; and (vii) Urban Poverty Reduction Program (P2KP) and Sub District Development Program (PPK) until direct cash assistance due to the fuel crisis. However, the efforts to eradicate poverty have become less successful or effective for several reasons: first, these programs are planned by the government on the basis of wrong perceptions and assumptions about the causes of poverty. Second, the plan of anti-poverty programs is carried out uniformly in terms of implementation form and model without regard to the various definitions and causes of poverty. Third, the lack of monitoring from the government towards the implementation of antipoverty programs which results in irregularities both in terms of program recipient selection and the costs incurred to the program implement. Fourth is the lack of research support on poverty 
issues, and evaluation of the impact of antipoverty programs on improving the lives of the poor (Soetrisno, 1997).

One aspect related to the poverty data which is currently considered important is the explanation of poor family distribution geographically. This is very important in program interventions, especially related to the widest possible access provided to poor families regarding the various services which can help them improve their level of welfare. In addition, a better understanding of the factors which have been the cause of poverty is needed, including a number of factors which perpetuate it. The most severe distribution of the poor community is in coastal communities and islands spread throughout Indonesia, including in South Sulawesi. Almost all regions in South Sulawesi have coastal and islands areas, including: Maros, Pangkep, Barru, Pare-Pare and Pinrang Districts for the North Sulawesi region. Whereas in the South covers almost all regions, including: Makassar, Gowa, Takalar, Jeneponto, Bantaeng, Bulukumba and Selayar. In this area, the poor population is almost entirely located in coastal and islands areas. Therefore, a research which examines poverty and its causes and opportunities to pursue alternative livelihoods in addition to managing the sea is a solution to alleviating poverty. This research aimed to describe the characteristics of poor households including; age, education and main occupation and its relationship to the poor household income level of coastal communities in South Sulawesi (Jayaraman, 2016).

\section{The Concept of Poverty}

Poverty is an ancient humanitarian problem. Poverty is latent and actual and has existed since human civilization existed and is still becoming a central problem in any hemisphere. Poverty is a dominant factor affecting other humanitarian issues such as backwardness, ignorance and neglect. Problems with illiteracy, dropping out of school, street children, child labor, and human trafficking cannot be separated from the problem of poverty. According to the United Nations Center for Human Settlements, poverty is more than just a person's inability to earn income, but also refers to the absence of physical abilities, assets and income to meet person's standard needs. Another definition of poverty is stated by Panjaitan (2002) that, poverty is defined as a low standard of living, it is the existence of material deficiency level in a number of people compared to the living standard which is generally applicable in the community concerned.

Ala (1996) defines poverty as an inequality of opportunity to accumulate a basis of social power. The basis of social power includes (not limited to) productive capital or assets (for example: sociopolitical organizations which can be used to achieve common interests of political parties, syndicates, cooperatives, etc.), networks or social networks to obtain employment, goods, adequate knowledge and skills, and information which is useful for advancing their lives.

According to Suyanto (1995) poverty can be divided into three terms: absolute poverty, relative poverty and cultural poverty. Someone can be included to the absolute poor if the income is below the poverty line, which is not enough to meet the minimum living needs such as food, clothing, health, shelter, and education. Someone who is classified as relative poor has actually lived above the poverty line but is still below the capacity of the surrounding community. Then, cultural poverty is closely related to the attitude of a person or group of people who do not want to try to improve their level of life even though there is an effort from another party who helps them. Craig, et al (1995) state that absolute poverty is that if someone's income is below the absolute poverty line, which is a certain measure that has been set where the minimum needs can still be fulfilled, in other words the income is sufficient to meet the minimum needs set in the poverty line. Penny (1992), relative poverty is the comparison condition among income groups in society. 
The characteristics of those who live below the poverty line are, first, they generally do not have their own factors of production, such as sufficient land, capital or skills. Second, they do not have the possibility to obtain production assets by their own strength. Third, they have low education level. Fourth, many of them live in rural areas and do not have land. Even if they have the land, it is very narrow. And fifth, many of those who live in cities are still young and have no skills or education.

\section{Size of Poverty}

According to Djojohadikusumo (Partadireja, 1993), there are five kinds of poverty indicators: food, clothing, housing, health and education. The five are below a certain poverty line called the absolute poverty line.

The size or indicator of poverty between one region and another is also different. The results of research conducted by Soetrisno (1997) show that for the Javanese, the poor are indicated by the following indications: (1) slum house, (2) do not have clothes which are good enough to attend a meeting, (3) do not have a permanent job, (4) do not have food supplies, (5) do not have land or large livestock. Whereas the indicator of poverty for Aceh people is what they generally call "lack", it is the difficulty of Aceh people in accessing various education, health facilities, connecting roads from the sub-district to the villages which are important to sell their agricultural products.

\section{Research Methodology}

The population of this research was the whole poor population who live in coastal areas in South Sulawesi with an analysis unit of poor households. The data analysis method used in this research was descriptive analysis to find out the general description of the poor households' characteristics and Chi-Square Analysis to determine the relationship between social characteristics and poor household income.

\section{Result and Discussion}

Referring to the research objective, which was to describe the characteristics of demography, social and economic household, and analyze the relationship between the poor households' characteristics and income levels in 9 districts and cities in South Sulawesi province. The analysis and discussion of the research will be described systematically as follows.

\section{Age Characteristics}

Respondent analysis based on age group aimed to distinguish whether the respondents were in the productive or less productive age groups. In this research, it was assumed that the productive age group ranges from 18 to 50 years, whereas the less productive ones are more than 50 years old (Figure 1). Based on Figure 1, it appeared that the respondents who were in productive age from the total respondents were 205 people (75 percent) of 273 respondents being researched. The remaining 25 percent or 68 people out of the total respondents were in less productive age.

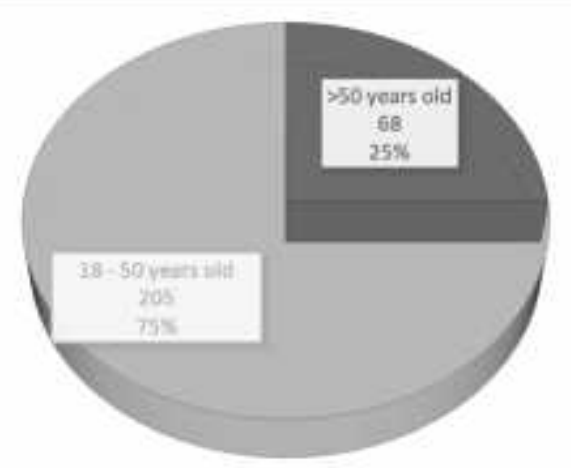

Fig. 1. Distribution of Respondents Based on Age

\section{Characteristics of Education}

Considering from the formal education level which had ever been taken by the respondents, the largest number of respondents were respondents who did not complete the primary school, in the amount of 25 percent or 68 people, followed by elementary education level with the number of 115 people or 42 percent from the total respondents. At the junior high school level, there were 51 people or 19 percent, while the smallest were respondents with a high school level and above which was 14 percent or 39 people. For 
more details, the distribution of respondents according to education could be seen in Figure 2.

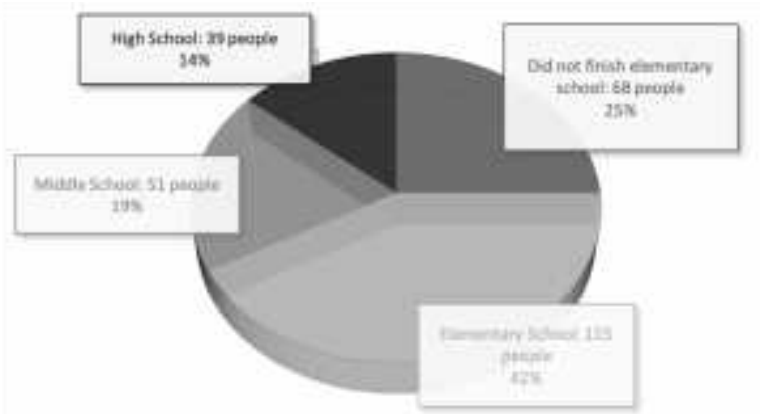

Fig. 2. Distribution of Respondents Based on Education Level

\section{Characteristics of Main Occupation}

From 273 respondents selected as sample members of this research, there were 57.88 percent or 158 respondents whose main occupation was fishermen, 30 (11 percent) respondents worked as farmers, while 6 percent (17 people) and 24 percent (65 person) of the total respondents who work as traders and services workers. For more details, the distribution of respondents according to the level of education could be seen in Figure 3.

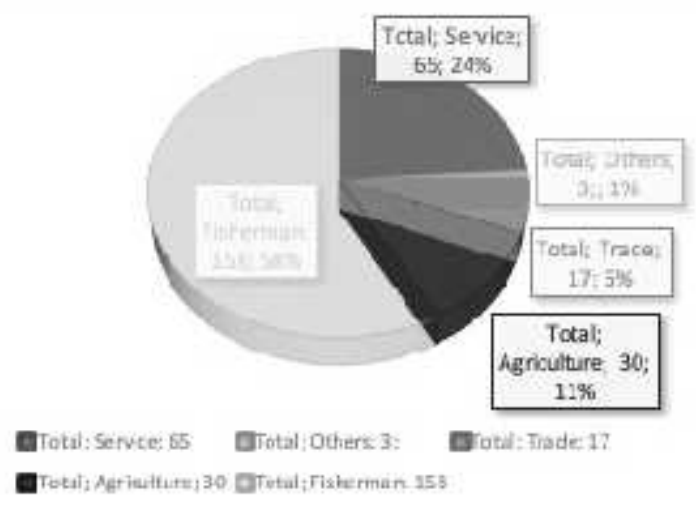

Fig. 3. Distribution of Respondents Based on Main Occupation

\section{Characteristics of Income}

From the total respondents selected in the research, there were 20 percent or 56 respondents had an average income per family member in the highest amount of below Rp. 1,000,000 per month, 62 respondents (23 percent) who had an average family income of Rp. 1,000,000 - Rp. 2,000,000 per month. Then, 35 percent of respondents had an average family income of more than Rp. 3,000,000 per month. This showed that 56 families of respondents were at the poverty level (Figure 4).

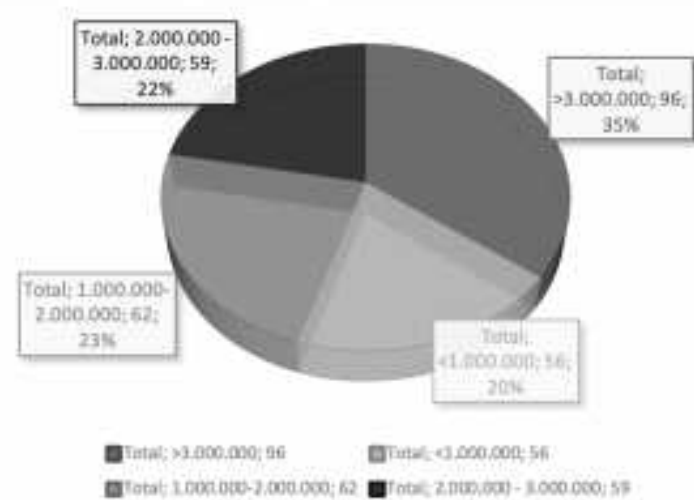

Fig. 4. Distribution of Respondents Based on Income Level

\section{The Relationship of Household Head Age with Household Income Per Capita}

The distribution of households based on the age of household head tended to be in the productive age, which was in the amount of 28.9 percent (30-40) years and 26.4 percent (31-50) years. If we look further with the statistical test, it appeared that there was a significant difference in the proportion of household income based on the age of household head. This showed that there was a significant relationship between the age of household head and household income, where the Pearson Chi-Square value was 0.001 smaller than the significance level of 5\% (0.05). This showed that among poor households the more senior household heads were more productive. If these conditions were associated with human capital theory, it was evident that working experience (age proxy) had a positive effect on the productivity of workforce (Becker, 1993). The implications of this research results proved that the development of SMD quality in the poor community was still needed. 


\section{The Relationship of Household Heads Education with Household Income Per Capita}

Theoretically, Anderson (1983), Ehrenberg, et al (2000), and McConnell (1999), have illustrated through the graph related to the relationship of education to annual income (annual earnings). Then Becker (1993) defines that human capital from a person's knowledge will encourage work productivity and will in turn receive remuneration (income) which is assumed to be equal to the marginal productivity value (VMPPl).

The results of this research support the human capital theory, where formal education is positively and significantly related to household income per capita. If the trend is further analyzed, it appears that there is a significant relationship between the education level and poor household income per capita, where the Pearson Chi-Square value of 0.002 is smaller than the significance level of $5 \%$ (0.05). This indicates that the education level of household is Human Resources investment which needs to be developed in order to encourage work productivity which will then encourage increased income or reduce the poverty rate of the community.

This research results support the results of previous studies, such as Belzil (2000) who researched on "The data base for market research, Wheeler (2001) who used data from the countries and metropolitan areas, USA, 1999, Bound (2000) who used Metropolitan statistical data areas, and Bloeman (2001) used Socio-economic panel data (SEP, 1987-1990). They found that education and work experience had positive and significant influence on income levels. This showed that the results of this research helped enrich the scientific knowledge, especially in the human capital theory. Thus, education is increasingly difficult to refute as a major human capital, after work experience and natural innate and social environment.

In this case, low income (business results), skills and education are an inseparable link. Both are interconnected and have an effect. According to Jalaludin Rachmat (1999), low productivity, low income caused low education. Low education results in low quality of human resources (HR). The low quality of human resources leads to low productivity and so on. This view is said to be a vicious circle or a vicious circle of poverty.

\section{The Relationship between the Kinds of Work of Household Head and Household Income Per Capita}

The distribution of household heads based on income per capita and kinds of works show that there is a difference in household income patterns per capita based on the kinds of work. It appears that workers engaged in non-primary sector (artisan and trade) have the opportunity to get household income per capita relatively higher than the primary sector (farming and fishing). If we look further with statistical tests, it appears that there is a significant difference in the income per capita among many kinds of work. Statistical test results show a significant relationship, where the Pearson Chi-Square value is 0.001 smaller than the significance level of $5 \%(0.05)$. This shows that this research results support the theory, that the primary sector work productivity is relatively lower than in other sectors, where the primary sector tends to work and the sector is very unstable towards certain seasons and climates while the non-primary sector is relatively not related to the time, season and certain climate.

The characteristics of poverty and alternative livelihoods for the sustainability of coastal communities in 9 districts/cities in South Sulawesi Province which include; sex, marital status, number of family members, age, formal education, informal education, ability to read and write, ability to use Indonesian language, main occupation, family income per capita, family income, home ownership status, social activities, help from others, land ownership, machine ownership, savings ownership, boat ownership, vehicle ownership, and monthly expenses. In general, it has the same characteristics between the poor in coastal communities (fishermen), farmers (remote areas), and urban in Indonesia. However, there are variations in the results of 
previous studies, such as the status of the main and side jobs which do not have differences in family income.

The relationship between these socioeconomic characteristics and the family income level is concluded that in the poor coastal community, productive age is very important to obtain better family income in order to maintain future socioeconomic welfare. Because the coastal communities work generally relies heavily on physical strength, then the power and the number of people determine the income output. Therefore, the desire to have a large number of families is an option, but on the other hand, the implications actually decrease the amount of family income.

With the addition of family members, it is not comparable to the additional family income, and will certainly affect the level of family economic welfare. Formal education and informal education turned out to also become a major need for the coastal poor communities, but the choice between the consumption today as capital investment for the long term requires that they prefer the first. This means that this free education program for groups of poor coastal communities has become their hope for the government. The activeness in various institutions is important to build the character and motivation of poor coastal communities to get out of the poverty circle. However, for them, social activities have no impact on family income so they tend to be avoided or had not been carried out at all. Various institutional and social activities are needed on improving the family's economy.

The existence of side jobs (alternative), in addition to the main jobs as coastal fishermen, farmers, trade or other service sectors, should have an impact on increasing family income. However, the research results show that there is no difference between the main occupation and the side job. It means that side jobs are still part of the main job which does not have an impact on additional family income. Therefore, alternative livelihoods outside the main work need to be developed.
The alternative livelihoods in the service sector should be an option because it turns out that the non-primary sector (artisan and trade) has the opportunity to earn more income than the primary sector (fishermen and farmers). The efforts in this direction can be made, considering that poor coastal people also have the same preferences as other communities in terms of developing human resource capabilities. It means that they can be educated in their knowledge and skills to develop a wider area of work which can have an impact on increasing family income.

\section{Conclusion and Recommendation}

\subsection{Recommendation}

1. Providing broad opportunities for coastal village communities to obtain adequate and free education services. The government needs to develop a national education system which focuses on the alignments with coastal poor people (formal education and informal education for poor coastal people). Education offered in Indonesia is currently very expensive and the costs are difficult to reach by poor coastal people. Therefore, they choose not to send their children to school, because the burden of education costs is not comparable to the financial capacity of their families. Coastal village communities always say that "It has been difficult for us to survive every day; we don't think we are able to send our children to school". So, the poor coastal communities is only limited to survival.

2. Redistribution of business ownership for the poor coastal community assets need a strong struggle in managing the natural environment in the form of land ownership, machinery, savings, fishing boats, vehicles, by calculating balanced monthly expenditure and business capital. The inequality of agricultural land ownership widens the gap of poverty between people living in rural areas. Most 
of the fertile agricultural lands are owned by local middlemen and landlords. As a result, the existing agricultural lands do not provide sufficient income for rural people who have limited land and agricultural capital. Most of their energy and physical use are used as laborers on agricultural lands owned by landlords and local middlemen as well as ownership of machinery and fishing boats are also controlled by the middlemen as collectors by utilizing the workers of the poor coastal people.

3. The government should use its function to empower poor coastal communities by providing fishermen technology infrastructure to rural areas. The opening of fisheries investment can provide employment opportunities for rural communities. That way, their income will increase and affect changes in the economic welfare of the poor.

4. Opening wide opportunities for poor coastal communities to obtain easy business loans. The current credit system has not provided business facilities for rural communities and is often misdirected. Therefore, a new policy is needed which provides adequate business credit guarantees for the poor coastal communities.

5. Fulfilling the needs of clothing, food, and housing of the poor coastal people. The need of clothing, housing and food needs to be carried out through a village barn mechanism which provides equal opportunities to the village community, obtaining resources provided in an organized manner.

6. Introducing a modern fisheries technology system with appropriate technology which makes it easy for poor coastal communities to explore adequate sources of income. Fisheries technology is multiplied and given for free to the coastal fishermen to increase fishery productivity and facilitate the fulfillment of their living needs.

7. Providing health insurance to the community with a free health care system, increasing the number of local governmental health service center and health service units to poor and underdeveloped rural communities.

8. Providing insurance and social security guarantees for the poor coastal communities. Insurance and social security guarantees can improve the life quality of the poor coastal communities and provide more meaningful spirit of life. The current insurance and social security system, applied in a discriminatory manner, is only limited to those who have money. For this reason, the government is obliged to provide adequate insurance coverage to the poor coastal community.

9. Strengthening the executive and legislative commitments to improve the governance. The current governance structure provides freedom for corruption practices to occur at all levels of government. Improving the governance system is a key word to make poverty reduction programs truly intended for the poor coastal communities.

10. Encouraging the regional development agenda to prioritize poverty eradication as the main priority scale, encouraging the determination of all parties to acknowledge the poverty reduction failure so far, raising collective awareness to understand poverty as a common enemy, and increasing the participation of all parties in eradicating poverty.

In order to support the sustainability of poor coastal community, these patterns and strategies are needed. The following elements are needed:

1. The poverty reduction efforts should be carried out in a comprehensive, integrated, cross-sectoral manner and in accordance with local conditions and culture, because 
there is no poverty policy which is suitable for all; pay attention to the process aspects, without neglecting the end result of the process. Let the poor feel how their process can get out of the vicious circle of poverty.

2. Involving and are the results of a dialogue process with various parties and consultants with all interested parties, especially the poor community.

3. Increasing awareness and concern among all relevant parties, as well as arousing the passion of those who are involved to take an appropriate role in order to create a sense of belonging to the poverty programs and alternative livelihoods for coastal communities.

4. Providing the widest possible space for the emergence of various community initiatives and creativity at various levels. In this case, the government plays a role as an initiator, and then acts as a facilitator in the process, so that ultimately, the framework and approach to poverty reduction are mutually agreed.

5. The government and other parties (NGOs, universities, businessmen, civil society, political parties and socio-religious institutions) can join into mutually supportive forces.

6. Those who are responsible for preparing the budget should be aware of the poverty alleviation importance for alternative sustainable livelihoods for coastal communities so that these efforts are placed and receive top priority in each program of each agency. Thus, poverty reduction becomes a movement from, by and for the people for the economic welfare of the poor coastal community.

\subsection{Conclusion}

The characteristics of poverty and alternative livelihoods for the sustainability of coastal communities in 9 districts/cities in South Sulawesi
Province include; age, formal education, main occupation, family income per capita. In general, poor coastal community has the same characteristics as the poor in general, between fishermen, farmers (remote areas), and urban in Indonesia. The characteristics of age, education and main occupation have a significant relationship to the family income.

The relationship between these socioeconomic characteristics and the level of family income is concluded that in the poor coastal community, productive age, education and employment are very important to obtain better family income in order to maintain future socioeconomic welfare.

\section{References}

[1] Ala, Andre Bayo. 1996. Kemiskinan dan Strategi Memerangi Kemiskinan. Yogyakarta: Liberty.

[2] Anderson, W.H. Locke, 1983. Economics. Prentice-Hall, Inc., Englewood Cliffs, N.J., USA

[3] Becker, Gary S. 1993. Human Capital, A Theoretical and Empirical Analysis with Special Reference to Education. Third Edition. The University of Chicago Press

[4] Belzil, Chiristian, 2000. Job Creation and Job Destruction, Worker Reallocation, and Wages: Journal Labor Economics, Vol. 18 (183-203), The University of Chicago Press, Chicago

[5] Bloeman, Hans G and Elena G. F. Stancanelli, 2001. Individual Wealth, Reservation Wages, and Transitions into Employment. Journal Labor Economics, Vol. 19 (401-439), The University of Chicago Press, Chicago

[6] Craig, Gary, Mayo, Marjorie, 1995. Community Empowerment: A Reader in Participation and Development. Zed Books Ltd., London

[7] Ehrenberg, Ronald G, Robert S. Smith, 2000. "Modern Labor Economic". Seventh 
Edition, Addison Wesley Longman, Inc.

USA

[8] Jayaraman, S Gigi G.(2016) Disaster and Assembled Victim Management In A Hospital International Journal of Applied Services Marketing Perspectives $(0$ Pezzottaite Journal Volume 5, Number 4, October ISSN (Print): 2279-0977, (Online): 2279-0985

[9] McConnell, Campbell R. and Stanley L. Brue. 1999. Contemporary Labor Economics, First Edition, Mc Graw-Hill International Editions, Singapore

[10] Partadireja, 1993. Pengantar Ekonomi. BPEE. Yogyakarta

[11] Penny, D.H., 1992. Kemiskinan Peranan Sistem Pasar. Universitas Indonesia Press. Jakarta

[12] Rakhmat, Jalaluddin. 1999. Metode Penelitian Komunikasi. Bandung, PT. Remaja Rosda Karya

[13] Soetrisno, L, $1997 . \quad$ Kemiskinan, Perempuan dan Pemberdayaannya. Kanisius. Yogyakarta

[14] Suyanto, B, 1995. Kemiskinan dan Kebijakan Pembangunan. Kumpulan Hasil Penelitian. Aditya Media. Yogyakarta

[15] Wheeler, Christopher H, 2001. Search, Sorting and Urban Agglomeraton: Journal Labor Economics, Vol. 19 (879-948), The University of Chicago Press, Chicago

[16] Panjaitan, M., 2000. Memberdayakan kaum miskin. BPK Gunung Mulia.

[17] Bound, J., 2000. Demand shifts, population adjustments, and labor market outcomes during the 1980s. Journal of labor Economics, 18(1), pp.20-54. 